\title{
EFFECT OF DIALYZER REUSE UPON UREA REDUCTION RATIO (URR), KT /V UREA AND SERUM ALBUMIN IN REGULAR HEMODIALYSIS PATIENT
}

\author{
Ni Made Amelia R. Dewi ${ }^{1}$, Budi Suprapti ${ }^{2}$, I Gde Raka Widiana ${ }^{3}$
}

\begin{abstract}
1. Post Graduate Program of Clinical Pharmacy,

Airlangga University, 60268

2. Department of Clinical

Pharmacy, Airlangga

University, 60268

3. Nephrology Unit, Internal

Medicine Department of RSUP Sanglah Denpasar Jalan Diponegoro, Denpasar, Bali 80114
\end{abstract}

Submitted: 02-03-2015

Revised: $12-04-2015$

Accepted: 15-06-2015

*Corresponding author Ni Made Amelia R. Dewi

Email:

truly_mely_deeply

@yahoo.com

\begin{abstract}
Reuse of dialyzers for hemodialysis can help in bringing down the cost of hemodialysis. On the other hand reuse of dialyzer may change dialyzer integrity. This study was undertaken to determine dialyzer reuse effect on Urea Reduction Ratio (URR), $\mathrm{Kt} / \mathrm{V}$ urea and serum albumin. This was prospective study in Sanglah Public General Hospital Denpasar. Inclusion criteria for this study were patients who receive hemodialysis more than 3 months on twice weekly hemodialysis. In the study we used hollow fiber or dialyzer Elisio type $\mathrm{H}-130 \mathrm{H}$ reprocessed with Renaline automatically by machine renatron. After each session blood urea, post dialysis weight and serum albumin were measured. Measurements was performed on the use new dialyzer, $1^{\text {st }}$ reuse, $4^{\text {th }}$ reuse and $7^{\text {th }}$ reuse. The dialyzer was discarded, if TCV fell below $80 \%$ of baseline value. Kt/ $\mathrm{V}$ and urea reduction ratio (URR) were calculated as measure of dialysis adequacy. A total of 23 people completed the study. There was a lack of uniformity duration of hemodialysis, so that we also performed an analysis using a uniform length hemodialysis duration (4.5 hours) with 15 samples. There were no significant difference between URR and Kt/V urea of new dialyzer and dialyzer reprocessed by renaline respectfully with $p=0.131$ and $p=0.373$. If we analyzed only using uniform time of dialysis $(4.5 \mathrm{~h})$ the value of URR and $\mathrm{Kt} / \mathrm{V}$ urea between new and reused dialyzer not significantly different with $p=0.520$ and $p=0.784$. There was also not found significant differences between serum albumin of the use new dialyzer and reused dialyzer by the time of uniform or nonuniform, respectfully with $p=0.271$ and 0.073 . Reuse dialyzer does not alter efficacy of hemodialysis.
\end{abstract}

Key words : Dialyzer, Urea Reduction Ratio (URR), Kt/N Urea, Albumin, Total Cell Volume (TCV)

\section{INTRODUCTION}

Hemodialysis in Indonesia started since 1970 and has been carried out until now. Hemodialysis is one of the medical interventions that need a lot of costs. Reuse of dialyzers for hemodialysis can help in bringing down the cost of hemodialysis (Prihanto, 2001). Reuse of the dialyzer may affect its performance as a result of deposition of blood elements inside the lumen of the blood compartment and on to the dialyzer membrane. Reprocessing procedure may also damage the membrane thus affecting the performance (Cheung et al., 1999).

Prihanto (2001) was using dialyzer nipro FB 100T reprocessed with formaldehyde and
$\mathrm{H} 2 \mathrm{O} 2$ found significant decrease of URR and $\mathrm{Kt} / \mathrm{V}$ urea on the $4^{\text {th }}$ reuse of dialyzer. Meanwhile Aggarwal, et al (2012) was using F6 dialyzer polysulfane processed using formaldehyde, reused for 3 times and found no significant difference in the value of URR and $\mathrm{Kt} / \mathrm{V}$ urea in to 3 groups of reuse (Aggarwal, et al., 2012).

Reuse and reprocessing dialyzer repeatedly may influenced hemodialysis due to the occurrence of binding molecule albumin on dialyzer membrane and even in certain circumstances albumin may leak during hem dialysis (Riyanti, 2001).

The use of bleaching or heated citric acid during reprocessing found to have a beneficial 
effect on the clearance of solute molecules are like beta-microglobulin, but decreased albumin levels were significantly on dialiser polysulfone (F80) if the processing is repeated with bleaching (Kaplan et al., 1995). This study was undertaken to determine dialyzer reuse effect on Urea Reduction Ratio (URR), Kt/V urea and serum albumin.

\section{MATERIAL AND METHODS}

This was a Prospective observational study using the Analytical measurement of BUN and serum albumin pre and post hemodialysis in Sanglah Public Hospital Denpasar. Measurements made on the use of new dialyzer, $1^{\text {st, }} 4^{\text {th }}$ and $7^{\text {th }}$ reuse first. Inclusion criteria for this study were patients who receive hemodialysis more than 3 months (chronic Hemodialysis) with frequency twice a week. Patients with unstable conditions: sepsis, shock, positive HBsAg (secondary data) and HIV-positive are not included in the study. We used bicarbonate as a buffering agent and Elisio type $\mathrm{H}-130 \mathrm{H}$ dialyzer reprocessed using Renalin automatically by machine renatron in this study. Blood flow ranged from $200-300 \mathrm{~mL} / \mathrm{min}$ and dialysate flow rate was fixed at $500 \mathrm{~mL} / \mathrm{min}$. Dialyzers were discarded if the TCV fell to $<80 \%$ of its initial value.

URR was calculated using following formula

$$
\mathbf{U R R}=\frac{\left(\mathrm{U}_{\text {pre}}-\mathbf{U}_{\text {post }}\right)}{\mathbf{U}_{\text {pre }}} \times 100
$$

Where, $\mathrm{U}_{\mathrm{pre}}$ and $\mathrm{U}$ post are predialysis and postdialysis urea level respectively.

$\mathrm{Kt} / \mathrm{V}$ was calculated by using Daugirdas $2^{\text {nd }}$ generation formula

$$
{ }^{\prime} \mathrm{Kt} / \mathrm{V}^{\prime} \frac{-\ln [\mathrm{R}-0.03]+[4-3.5 \mathrm{R}] \times \mathrm{UF}}{\mathrm{w}}
$$

Where, $\mathrm{R}=$ Post $\mathrm{BUN} /$ Pre BUN; UF = Achieved ultrafiltration; $\mathrm{w}=$ Postdialysis weight.

Repeated Anova test was used to compare the means of URR, Kt/V and albumin between the groups. We also try to correlate between TCV value with URR and $\mathrm{Kt} / \mathrm{V}$, because lost of $20 \% \mathrm{TCV}$ was correlated with $10 \%$ of decrease urea clearance (Gotch, et al., 1999), using Spearman correlation analysis.

\section{RESULTS AND DISCUSSION}

Fifty patients agreed to participate in the study, but only a total of 23 people completed the study. We also performed an analysis using uniform length hemodialysis duration (4.5h) with 15 samples, because there was a lack of uniformity duration of hemodialysis.

Patients who followed this research is dominated by the male gender. Etiologies of Chronic Kidney Diseases are most due to chronic pyelonephritis. Blood flow rate ranges between $200-300 \mathrm{~mL} / \mathrm{min}$.

In statistical test showed that there were no significant difference of the average between URR and Kt / V urea from new dialyzer and dialyzer reprocessed with Renalin with $\mathrm{p}=0.131$ and $\mathrm{p}=0.373$

Because there is a lack of uniformity duration of hemodialysis, we also performed an analysis with a uniform length of time hemodialysis is $4.5 \mathrm{~h}$ which were obtained by the value of URR and Kt/V urea between the type of tube dialyzer not significantly different with $p=0.520$ for URR and $p=0.784$ for $\mathrm{Kt} / \mathrm{V}$.

Lobo et al. in a prospective study found that there was no significant difference in the value of $\mathrm{Kt} / \mathrm{V}$ on repetitive processing up to 6 times using dialyzer type F6 (Lobo et al., 2002). In another study also found no significant difference using cellulose diacetate dialyzer processed manually repeated up to 9 times (Manandhar et al., 2009). Aggarwal et al, (2012) using F6 dialyzer polysulfane processed using formaldehyde and reused for 3 times and found no significant difference in the value of $\mathrm{URR}$ and $\mathrm{Kt} / \mathrm{V}$ in to 3 groups of re-use (Aggarwal et al., 2012)

Repeated use dialyzer can cause a decrease in the effective surface of the membrane pore size, depending on the techniques and methods of reprocessing. This can occur even though the residual total cell volume (TCV) remained above $80 \%$ of the value of new dialyzer. Decreasing the number of effective volume and pore size caused by formation of a layer of protein that will cause a decrease in urea clearance dialyzer (Ahmad. 2009). 
Table I. Number of sample

\begin{tabular}{ccc}
\hline Dialyser & Sample (Non uniform time) & Sample (uniform time $=\mathbf{4 . 5 h}$ \\
\hline New & 50 people & 30 people \\
$1^{\text {st }}$ Reuse & 47 people & 28 people \\
$4^{\text {th }}$ Reuse & 36 people & 22 people \\
$7^{\text {th }}$ Reuse & 23 people & 15 people \\
\hline
\end{tabular}

Table II. Sample characteristics

\begin{tabular}{lcc}
\hline \multirow{2}{*}{ Sample Characteristic } & $\mathbf{N}=\mathbf{2 3}$ (Non uniform time) & $\mathbf{N = 1 5}$ (uniform time) \\
\cline { 2 - 3 } & Average (SD) /(\%) & Average (SD) /(\%) \\
\hline Age (Years) & $44.09 \pm 11.7$ & $47.37 \pm 11.93$ \\
Sex (\%) & $56 \%$ & \\
$\quad$ Male & $44 \%$ & $53.33 \%$ \\
$\quad$ Female & & $46.67 \%$ \\
Etiology (\%) & $87 \%$ & $80 \%$ \\
$\quad$ PNC & $9 \%$ & $13.33 \%$ \\
GNC & $4 \%$ & $6.67 \%$ \\
DMND & $55.66 \pm 11.72$ & $56.78 \pm 14.77$ \\
Dry Weight $(\mathrm{Kg})$ & $4 \pm 2.3$ & 4.5 \\
Duration (Hour) & $251.30 \pm 24.22$ & $258.62 \pm 25.99$ \\
Blood flow (ml/minutes) & & \\
Ultra filtration & $3.17 \pm 1.00$ & $3.09 \pm 1.06$ \\
Volume(Liter) &
\end{tabular}

Table III. Delivered dialysis dose of URR from new and reuse dialyzer

\begin{tabular}{|c|c|c|}
\hline Dialyzer & $\begin{array}{l}\text { URR average } \pm \text { SD (non uniform time) } \\
\qquad(\mathrm{N}=23)\end{array}$ & $\begin{array}{l}\text { URR average } \pm \text { SD (uniform time) } \\
\qquad(N=15)\end{array}$ \\
\hline New & $73.48 \pm 7.94$ & $77.47 \pm 5.48$ \\
\hline 1st Reuse & $72.58 \pm 8.05$ & $76.64 \pm 5.96$ \\
\hline $4^{\text {th }}$ Reuse & $73.19 \pm 7.56$ & $76.97 \pm 5.93$ \\
\hline 7th Reuse & $72.86 \pm 8.01$ & $77.07 \pm 6.31$ \\
\hline P Value & 0.131 (Not Significant) & 0.520 (Not Significant) \\
\hline
\end{tabular}

Table IV. Delivered dialysis dose of Kt/V from new and Reuse Dialyzer

\begin{tabular}{|c|c|c|}
\hline Dialyzer & $\begin{array}{c}\mathrm{Kt} / \mathrm{V} \text { average } \pm \mathrm{SD} \text { (non uniform } \\
\text { time) }(\mathrm{N}=23)\end{array}$ & $\begin{array}{c}\mathrm{Kt} / \mathrm{V} \text { average } \pm \mathrm{SD} \text { (uniform } \\
\text { time) }(\mathrm{N}=15)\end{array}$ \\
\hline New & $1.70 \pm 0.38$ & $1.89 \pm 0.32$ \\
\hline 1st Reuse & $1.65 \pm 0.39$ & $1.86 \pm 0.34$ \\
\hline $4^{\text {th }}$ Reuse & $1.66 \pm 0.37$ & $1.85 \pm 0.38$ \\
\hline 7th Reuse & $1.69 \pm 0.41$ & $1.88 \pm 0.33$ \\
\hline P Value & 0.373 (Not Significant) & 0.784 (Not Significant) \\
\hline
\end{tabular}

The accumulation of protein adsorption or blood clot on the membrane, after the process of reuse causing decrease in membrane performance by the presence of a secondary layer of plasma components. It can reduce the diffusion layer and close the pores thereby reducing disposal solute (Azar. 2009 and Canaud. 2014). In this study only used dialyzer qualified TCV above $80 \%$, resulting in the absence of significant differences between URR 
and $\mathrm{Kt} / \mathrm{V}$ urea of new dialyzer and dialyzer reused.

In the measurement of serum albumin was also not found significant differences between the use of a new tube and the tubes were reused by the time of uniform or nonuniform, with $\mathrm{p}=0.271$ and 0.073 .

In the study found no significant differences in albumin from the beginning to the end of the study. Albumin levels tend to rise after the hemodialysis process can be seen from the differences of albumin which tend to be positive. This condition is due to the possibility that the increased level of albumin post hemodialysis is due to the reduced concentration of the liquid so that the concentration of serum albumin is increased.

Riyanti (2001) reported that there was obtained a statistically significant difference between the difference of serum albumin in serum pre- and post-hemodialysis for various status dialyzer uses. Aggarwal, et al (2012) found no significant differences in serum albumin pre and post on dialyzer repeated use. In another study it was found that there were no significant differences in serum albumin levels through the use of repetitive dialyzer to 13 times (Ahmed et al., 2001).

We also try to correlate between TCV value with URR and $\mathrm{Kt} / \mathrm{V}$. because lost of $20 \%$ TCV was correlated with $10 \%$ of decrease urea clearance (Gotch et al., 1999). Spearman correlation analysis of the results obtained in the weak correlation between TCV relationship with URR values $(\mathrm{r}=-0.044)$ and TCV relationship with $\mathrm{Kt} / \mathrm{V} \quad(\mathrm{R}=-0.058)$, with $\mathrm{p}=0.676$ and 0.585 for the URR for TCV. If the samples are analyzed only with uniform time of $4.5 \mathrm{~h}$ is obtained $\mathrm{r}$ value of -0.031 $(p=0.813)$ on the relationship between TCV and URR while the $r$ value of -0.087 obtained $(\mathrm{p}=0.511)$

There were no correlations between the value of TCV with URR values and KT / V urea. This is probably due to the TCV value of new dialyzer is not measured and still considered as $100 \%$. The absent of measurement of new dialyzer TCV on new tubes can result in TCV value becomes less accurate because there is still a possibility that the TCV dialyzer not in hundred percent state.
In addition, the use of repeated dialyzer TCV value is only made up $80 \%$ so that the measurement range becomes narrow and no significant decrease in the value of URR and $\mathrm{Kt} / \mathrm{V}$ urea.

Several studies showed a reduction in the surface area of the protein material dialyzer result of the patient's blood that can lead to decreased clearance of urea. Lobo et al (2002) reported that there is a positive correlation between TCV and Kt/V dialyzer polysulfide (0.71) and cellulose diacetate (0.69). Gotch reported that as much as $20 \%$ reduction in total cell volume does not have a significant effect on the clearance of small molecules (Gotch et al., 1999). Studies show that a decrease in the area of the membrane can be partially compensated by increasing the blood flow rate.

Ouseph reported that urea clearance with parameters $\mathrm{Kt} / \mathrm{V}$ does not change significantly with TCV which is above $80 \%$, but decreased clearance of beta $2 \mathrm{TCV}$ used microglubin although still above 80\% (Ouseph et al., 1992). There are several others factors that contributed urea clearance beside Total Cell Volume such as blood flow rate, convective urea flux that occurs with ultra filtration, volume distribution of urea and vascular access.

\section{CONCLUSION}

The use of repeated dialyzer does not give effect to the value of Urea Reduction Ratio (URR), Kt/V urea also albumin serum levels of $1^{\text {st }}, 4^{\text {th }}$ and $7^{\text {th }}$ reused dialyzer that reprocessed with renalin.

\section{ACKNOWLEDGMENT}

Special thanks to all the nursing staff in hemodialysis unit of RSUP Sanglah for making this study a success. We are also indebted to Prof Raka and Prof Suwitra for all of the advice

\section{REFE RE NCES}

Aggarwal HK, Jain D, Shasney A, Bansal T, Yadhav RK, Kathuria KL, 2012. Effect of Dialyser Reuse on the Efficacy of Haemodialysis in Patients of Chronic Kidney Disease in Developing World. JIMS A. 2: 81-83.

Ahmed MH, Abed J, Tarif N, Alam A, Wakeel JS, Memon $\mathrm{N}$ et al, 2001. Dialyser reuse 
impact on dialyser efficiency, patient mortality and cost effectiveness. Saudi J Kidney Dis Transpl: 12:305-311

Azar, A.T, 2009. Increasing Dialysate Flow Rate Increases Dialyzer Urea Clearance and Dialysis Efficiency An In Vivo Study, Saudi J Kidney Dis. Transplant. 20(6), 1023-1029

Canaud, B. 2004. Adequacy target in hemodialysis. J. Nephrol. 17(8): S77-S86

Cheung AK, Agodoa LY, Daugirdas JT, Depner TA, Gotch FA, Greene T, Levin NW, Leypoldt JK. 1999. Effects of hemodialyzer reuse on clearances of urea and beta2-microglobulin. The Hemodialysis (HEMO) Study Group. J Am Soc Nephrol 10: 117-127

Gotch, F.A, 1980. Mass Transport in Reused Dialyzers. Proc. Clin. Dial. Transplant. Forum 10, 81-85

Kaplan A, Halley S, Lapkin R, Graeber C, 1980. Dialysate protein losses with bleach processed polysulfone dialyzers. Kidney Int 47: 573-578, 1995
Lobo V,Gang S , Shah LJ, Ganju A, Pandaya PK, Rajapurkar MM et al, 2001. Effect of hollow fiber dialysers reuse upon kt/v(urea). Indian J Nephrol: 12:40-48.

Manandhar DN, Chetri PK, Tiwar Ri, Lamichhane S, 2009. Evaluation of dialysis adequacy in patients underhemodialysis and effectiveness of dialysers reuses. Nepal Med Coll 11: 107110

Ouseph, R., Hutchison, C.A., Ward, R.A, 2008. Differences in solute removal by two high-flux membranes of nominally similar synthetic polymers. Nephrol. Dial. Transplant. 23(5), 1704-1712

Prihanto E., 2001, Perbandingan Klirens Urea (N) dan Rasio Penurunan Urea (N) Pada Ginjal Buatan Baru dan Ginjal Buatan yang Dipakai Berulang, Thesis, Universitas Diponegoro, Semarang

Rianti T., 2001. Pengaruh Penggunaan Ginjal Buatan (Dialiser) Berulang terhadap Kadar Serum Albumin, Thesis, Universitas Diponegoro, Semarang 